\title{
Endocrinologic, neurologic, and visual morbidity after treatment for craniopharyngioma
}

\author{
Michael E. Sughrue • Isaac Yang • Ari J. Kane • \\ Shanna Fang $\cdot$ Aaron J. Clark $\cdot$ Derrick Aranda • \\ Igor J. Barani $\cdot$ Andrew T. Parsa
}

Received: 19 March 2010/Accepted: 30 May 2010/Published online: 10 June 2010

(C) The Author(s) 2010. This article is published with open access at Springerlink.com

\begin{abstract}
Craniopharyngiomas are locally aggressive tumors which typically are focused in the sellar and suprasellar region near a number of critical neural and vascular structures mediating endocrinologic, behavioral, and visual functions. The present study aims to summarize and compare the published literature regarding morbidity resulting from treatment of craniopharyngioma. We performed a comprehensive search of the published English language literature to identify studies publishing outcome data of patients undergoing surgery for craniopharyngioma. Comparisons of the rates of endocrine, vascular, neurological, and visual complications were performed using Pearson's chi-squared test, and covariates of interest were fitted into a multivariate logistic regression model. In our data set, 540 patients underwent surgical resection of their tumor. 138 patients received biopsy alone followed by some form of radiotherapy. Mean overall follow-up for all patients in these studies was $54 \pm 1.8$ months. The overall rate of new endocrinopathy for all patients undergoing surgical resection of their mass was $37 \%(95 \% \mathrm{CI}=33-$ 41). Patients receiving GTR had over 2.5 times the rate of developing at least one endocrinopathy compared to patients receiving STR alone or STR + XRT (52 vs. 19 vs. 20\%, $\left.\chi^{2} P<0.00001\right)$. On multivariate analysis, GTR
\end{abstract}

M. E. Sughrue $\cdot$ I. Yang $\cdot$ A. J. Kane $\cdot$ S. Fang ·

A. J. Clark · D. Aranda · A. T. Parsa (凹)

Department of Neurological Surgery, University of California at

San Francisco, 505 Parnassus Ave.,

San Francisco CA 94117, USA

e-mail: ParsaA@Neurosurg.UCSF.Edu

\section{J. Barani}

Department of Radiation Oncology, University of California at San Francisco, 505 Parnassus Ave., San Francisco CA 94117, USA conferred a significant increase in the risk of endocrinopathy compared to STR + XRT $(\mathrm{OR}=3.45,95 \% \mathrm{CI}=$ 2.05-5.81, $P<0.00001$ ), after controlling for study size and the presence of significant hypothalamic involvement. There was a statistical trend towards worse visual outcomes in patients receiving XRT after STR compared to GTR or STR alone $(\mathrm{GTR}=3.5 \%$ vs. STR $2.1 \%$ vs. STR + XRT $6.4 \%, P=0.11)$. Given the difficulty in obtaining class 1 data regarding the treatment of this tumor, this study can serve as an estimate of expected outcomes for these patients, and guide decision making until these data are available.

Keywords Craniopharyngioma $\cdot$ Surgery $\cdot$ Morbidity · Radiotherapy · Radiosurgery

\section{Introduction}

Craniopharyngiomas are locally aggressive tumors which typically are focused in the sellar and suprasellar region near a number of critical neural and vascular structures mediating endocrinologic, behavioral, and visual functions. Multimodality therapy for these tumors can be challenging, given the significant potential for harm with any intervention involving the structures in this region, as well as the young age of many of the patients with these lesions.

For many years, gross total resection (GTR) was felt to be the treatment of choice, given the better rates of tumor control compared to subtotal resection (STR) alone, and the avoidance of radiotherapy in young patients. Experience with aggressive surgical resection has led some to conclude that a general goal of GTR in all cases might lead to unacceptable rates of endocrinologic and behavioral morbidity, and that GTR could be replaced with subtotal 
debulking followed by stereotactic conformal radiotherapy [1-4]. This potential benefit must be tempered against the risk of radiation induced injury to nearby radiosensitive normal structures, notably the optic chiasm [5, 6]. The present study aims to summarize and compare the published literature regarding morbidity resulting from treatment of craniopharyngioma.

\section{Materials and methods}

Article selection

Articles were identified via a PubMed search using the key phrases "craniopharyngioma," alone and in combination with "optic," "morbidity," "pituitary," "hypopituitarism," "endocrine," "complications," "visual," and "vision." Inclusion criteria were: (1) All patients had to have follow-up data available. (2) Articles had to have enough information for each patient to be disaggregated. The rationale for the exclusion of aggregated data sets is described below. Exclusion criteria were: (1) Articles that combined patient outcomes of craniopharyngioma with other childhood tumors were excluded, unless there was a clear distinction between the two separate groups of patients. (2) Rathke's Pouch tumors were excluded from this study. After reviewing these articles, a thorough review of all referenced sources was also performed.

All references that contained disaggregated data specifically addressing complication rates with adequate follow up in patients who had undergone surgical resection with or without fXRT or stereotactic radiosurgery (SRS) as adjuvant or monotherapy were included in our analysis. In addition, we included patients undergoing surgery via the extended transsphenoidal route in the surgery cohort, where appropriate.

\section{Data extraction}

Our searches yielded a total of 274 studies [3, 7-279] (Table 1) reporting data for 8058 non-duplicated craniophayngioma patients. After analyzing the complication rates in aggregated cohorts, we concluded that complication rates were likely underreported in aggregated data sets (for example, the reported rate of endocrinopathy with GTR was $2.1 \%$ in the aggregated datasets, compared with a more realistic $52 \%$ in series which presented individual patients separately). Thus, we chose to analyze only these disaggregated datasets.

Disaggregated data useable for analysis were presented for 800 individual patients. Data were stratified into five groups based on treatment paradigm: STR alone, GTR alone, STR plus adjuvant post-operative radiotherapy
Table 1 Pubmed ID's of identified studies

\begin{tabular}{|c|c|c|c|c|c|}
\hline 102623 & 3984798 & 8607079 & 11322455 & 15141142 & 16700314 \\
\hline 290201 & 4084876 & 8748817 & 11345343 & 15185112 & 16700318 \\
\hline 290203 & 4308176 & 8869189 & 11441284 & 15206435 & 16798405 \\
\hline 290204 & 4542715 & 8869774 & 11465396 & 15272926 & 16825115 \\
\hline 290207 & 5059968 & 8883637 & 11515727 & 15290187 & 16850111 \\
\hline 408309 & 5573248 & 9007857 & 11585327 & 15322844 & 16888556 \\
\hline 430156 & 5648949 & 9068702 & 11685525 & 15335421 & 17015135 \\
\hline 615967 & 5821004 & 9112447 & 11740179 & 15367800 & 17041520 \\
\hline 622676 & 5842310 & 9224913 & 11769865 & 15558704 & 17042979 \\
\hline 928713 & 6156805 & 9298276 & 11810394 & 15570985 & 17046151 \\
\hline 975700 & 6168950 & 9361074 & 11841735 & 15670196 & 17161483 \\
\hline 1011020 & 6293388 & 9361075 & 11862438 & 15681858 & 17185886 \\
\hline 1110394 & 6381061 & 9364961 & 11938361 & 15759158 & 17233305 \\
\hline 1174243 & 6470759 & 9440495 & 11942362 & 15800425 & 17330531 \\
\hline 1403127 & 6511526 & 9482551 & 11949829 & 15807869 & 17337922 \\
\hline 1414528 & 6657077 & 9728244 & 11961313 & 15851090 & 17407137 \\
\hline 1527612 & 6673882 & 9782245 & 11981627 & 15871507 & 17415187 \\
\hline 1669245 & 6833018 & 9806520 & 11990811 & 15895298 & 17469176 \\
\hline 1727168 & 6853252 & 9814465 & 12060820 & 15928963 & 17533510 \\
\hline 1772600 & 6886754 & 9840379 & 12062594 & 15931512 & 17566208 \\
\hline 1803868 & 7099406 & 9950494 & 12099569 & 15957193 & 17592268 \\
\hline 1955511 & 7104980 & 9950495 & 12116534 & 15959732 & 17627142 \\
\hline 2002381 & 7105886 & 10066013 & 12134929 & 15959733 & 17762741 \\
\hline 2013769 & 7121821 & 10070421 & 12197795 & 15959734 & 18311527 \\
\hline 2080379 & 7264728 & 10086237 & 12243827 & 15959735 & \\
\hline 2095298 & 7413035 & 10232528 & 12376777 & 15965667 & \\
\hline 2116387 & 7431164 & 10424206 & 12382167 & 15971075 & \\
\hline 2204689 & 7438834 & 10433322 & 12419438 & 15989759 & \\
\hline 2311109 & 7530989 & 10445444 & 12420123 & 15995885 & \\
\hline 2352012 & 7530989 & 10461071 & 12447234 & 16001286 & \\
\hline 2398383 & 7568823 & 10616560 & 12456941 & 16028088 & \\
\hline 2441286 & 7596502 & 10616561 & 12495299 & 16034620 & \\
\hline 2494851 & 7616262 & 10659012 & 12507105 & 16044343 & \\
\hline 2501242 & 7619722 & 10681689 & 12507107 & 16055476 & \\
\hline 2672706 & 7673031 & 10690718 & 12555247 & 16124175 & \\
\hline 2689398 & 7818929 & 10703499 & 12677102 & 16133275 & \\
\hline 2894566 & 7841079 & 10726829 & 12786772 & 16133276 & \\
\hline 2912938 & 7841080 & 10760417 & 12820755 & 16133277 & \\
\hline 3336845 & 7841081 & 10867561 & 12823875 & 16175850 & \\
\hline 3396018 & 7841082 & 10883334 & 12825216 & 16216361 & \\
\hline 3396019 & 7841084 & 10892270 & 12845200 & 16320025 & \\
\hline 3442400 & 7841085 & 10975938 & 12922045 & 16327556 & \\
\hline 3489356 & 7885544 & 11013625 & 12925239 & 16383245 & \\
\hline 3628817 & 7942198 & 11014425 & 14519213 & 16500745 & \\
\hline 3712025 & 8021691 & 11118572 & 14558670 & 16580494 & \\
\hline 3738985 & 8027806 & 11124639 & 14961770 & 16630407 & \\
\hline 3794057 & 8272006 & 11131489 & 14967425 & 16700308 & \\
\hline 3799245 & 8327728 & 11143262 & 15035280 & 16700310 & \\
\hline 3968554 & 8422329 & 11155065 & 15040718 & 16700311 & \\
\hline 3968556 & 8438080 & 11234912 & 15046646 & 16700313 & \\
\hline
\end{tabular}


$(\mathrm{STR}+\mathrm{XRT})$, biopsy followed by fractionated radiotherapy (fXRT), or biopsy followed by radiosurgery (SRS) alone. We did not directly compare the radiation only groups (SRS and fXRT) to the surgically treated patients.

Endocrinopathy was defined as the development of any new monohormonal or polyhormonal anterior hypopituitarism, or diabetes insipidus. Vascular injury referred to any gross injury to the circle of Willis or perforating vessel, as well as any reported post-treatment cerebral infarction. Neurologic injury referred to the development of a posttreatment non-endocrine, non-visual neurologic deficit. Visual deterioration was defined as permanent loss or decrease in visual acuity, or a new visual field cut in either eye. Studies which did not present patient data in a way that these variables could reliably be determined were excluded from further analysis.

\section{Statistical analysis}

Pearson's $\chi^{2}$ test was used to analyze for differences in categorical factors. Fisher's exact test was used if there were less than five values per cell. Analysis of variance (ANOVA) was used to evaluate for statistical differences in pre-operative continuous factors, including age and tumor size. Post-hoc between group analyses were performed when the ANOVA demonstrated $P<0.05$ using Tukey's test. All analyses were carried out using SPSS version 16.0 (SPPS, Inc.).

\section{Logistic regression analysis}

Univariate analysis was used to identify covariates which might affect the rate of neurologic, endrocrinologic, vascular, or visual complications in these patients. Binary and categorical variables were compared using Pearson's $\chi^{2}$ test, or the $\chi^{2}$ test for trend, respectively. Cut-offs for variables were determined empirically by first analyzing the data in smaller categories, and then aggregating groups which seemed statistically homogeneous. Variables which impacted rates of complication with a $P=0.2$ or less on univariate analysis were included in stepwise binary logistic regression modeling [280]. All odds ratios on multivariate analysis, reflect the risk of having nonservicable hearing a neurologic or endocrine complication compared to the reference group. Reference groups included the STR + XRT cohort for the extent of resection analysis and the large sample size studies for the surgeon experience analysis. The goodness of fit of the regression model was confirmed by demonstrating a non-significant $P$-value on the Hosmer-Lemeshow test [280, 281].

We tested interaction terms between each of the three variables to significantly impact hearing on univariate analysis. The statistical significance of the interactions was assessed with the use of backward stepwise regression, in which statistical significance was estimated by means of the likelihood-ratio test to assess the effect of removing interaction terms for all strata of the given variable [280]. After finding that none of the interaction terms would significantly (unadjusted $P>0.2$ for all terms) alter the log likelihood of the regression model if removed, we calculated the adjusted odds ratios without adjusting for interactions.

Of note, while tumor size is a variable of interest, it is inconsistently presented in most studies, and we were only able to collect data on tumor size for 87 patients. Because these data were not enough to include in the multivariate regression modeling, we present only univariate data regarding the relationship between tumor size and complications.

\section{Results}

Clinical characteristics of included patients

In our data set, 540 patients underwent surgical resection of their tumor. GTR was achieved in 289 cases, while STR was achieved in 251 cases. Of patients receiving STR, 110 patients received fXRT, and 141 did not. Surgical patients in different cohorts did not differ in mean age at the time of surgery, gender distribution, or pre-operative tumor size.

138 patients received biopsy alone followed by some form of radiotherapy. 72/138 of these patients received fXRT, and 66/138 patients received SRS. Age and gender distribution did not differ between patients receiving fXRT and SRS.

The remaining patients did not have adequate data to facilitate our analysis and were excluded. Mean overall follow-up for all patients in these studies was $54 \pm$ 1.8 months.

The mean number of patients per study was 5.8 patients, (range 1-45 patients per study). $34 \%$ of the patients in the study came from series of 10 or less patients, $22 \%$ came from series of 10-20 patients, and 43\% came from series larger than 20 patients. The modest sample sizes in many of the included studies is an inevitable consequence of the decision to use only disaggregated data, as larger studies generally provide summary statistics instead of individual patient data, and as discussed below, frequently do not report rates of morbidity in a way which can be realistically analyzed.

The rates of neurologic injury after treatment for craniopharyngioma

New neurologic deficits were reported in $5.1 \%$ of patients undergoing surgery (95\% CI $=3.3-7.1)$, and in $2.2 \%$ of patients undergoing fXRT or SRS alone (95\% CI $=0-4.6$ ) 
Table 2 Summary of overall rates of morbidity

\begin{tabular}{ll}
\hline & $95 \%$ CI \\
\hline Endocrinopathy & \\
Surgery & $33-41$ \\
fXRT/SRS & $8.8-28$ \\
Vascular injury & \\
Surgery & $0-0.9$ \\
fXRT/SRS & 0 \\
Neurologic deficit & \\
Surgery & $3.3-7.1$ \\
fXRT/SRS & $0-4.6$ \\
Vision deterioration & \\
Surgery & $2.1-5.3$ \\
fXRT/SRS & $3.9-13.4$ \\
\hline
\end{tabular}

(Table 2). There was no statistically significant difference in the rates of neurologic deficits between patients receiving GTR alone, STR alone, or STR + XRT (6.9 vs. 4.2 vs. $1.8 \%, P=\mathrm{NS})$ in the univariate analysis, or between patients receiving fXRT and those receiving SRS (1.4 vs. $3.0 \%, P=\mathrm{NS}$ ) (Fig. 2).

Interestingly, on multivariate analysis, GTR conferred a significant increase in the risk of neurologic deficits compared to STR + XRT $(\mathrm{OR}=5.05,95 \% \mathrm{CI}=1.15-22.21$, $P=0.03$ ) (Table 5), after controlling for study size.

Gross total resection markedly increases the rate of endocrinopathy

The overall rate of new endocrinopathy for all patients undergoing surgical resection of their mass was $37 \%(95 \%$ $\mathrm{CI}=33-41)$ (Table 2). Table 3 summarizes the rates of individual endocrinopathies. Significant monoendocrinopathies of TSH and ACTH were reported commonly, as was diabetes insipidus (DI). Anterior panhypopituitarism was reported in as many as $11.8 \%$ in patients undergoing GTR.

Patients receiving GTR had over 2.5 times the rate of developing at least one endocrinopathy compared to patients receiving STR alone or STR + XRT (52 vs. 19 vs.

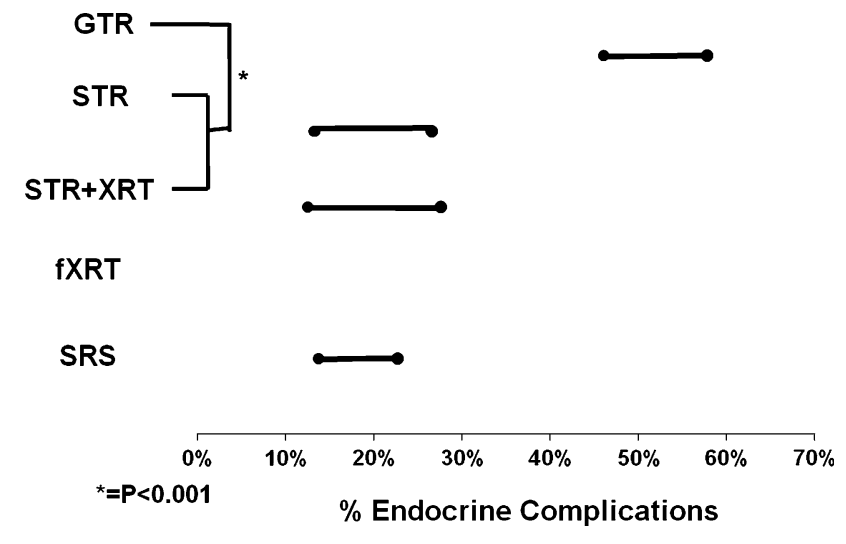

Fig. 1 Comparison of $95 \%$ confidence intervals of rates of endocrinopathy for patients treated with different modalities for craniopharyngioma

20\%, $\chi^{2} P<0.00001$ ) (Fig. 1). The rates of endocrinopathy for patients receiving fXRT alone were not reported, and thus these data were not analyzed.

On multivariate analysis, GTR conferred a significant increase in the risk of endocrinopathy compared to $\mathrm{STR}+\mathrm{XRT} \quad(\mathrm{OR}=3.45, \quad 95 \% \quad \mathrm{CI}=2.05-5.81$, $P<0.00001$ ) (Table 5), after controlling for study size and the presence of significant hypothalamic involvement.

The rates of vascular injury after surgery for craniopharyngioma

Vascular injury was an uncommon complication of craniopharyngioma surgery, occurring in just two cases $(95 \%$ $\mathrm{CI}=0-0.9$ ) (Table 2), both resulting in ischemic cerebral infarction. No vascular complications were reported in any patients undergoing radiation treatment alone.

The rates of visual decline after treatment for craniopharyngioma

Visual decline was reported in $3.7 \%$ of patients undergoing surgery $(95 \% \mathrm{CI}=2.1-5.3)$, and $8.6 \%$ of patients undergoing fXRT or SRS alone (95\% CI = 3.9-13.4) (Table 2).
Table 3 Summary of various types of monohormonal and polyhormonal endocrinopathy following treatment of craniopharyngioma

\begin{tabular}{lccccc}
\hline & GTR $(\%)$ & STR $(\%)$ & STR + XRT $(\%)$ & fXRT & SRS $(\%)$ \\
\hline Hyperprolactinemia & 0.0 & 0.0 & 0.9 & N/A & 0.0 \\
Hypogonadism & 3.5 & 2.1 & 1.8 & N/A & 3.0 \\
Hypothyroid & 13.8 & 5.7 & 1.8 & N/A & 7.6 \\
GH deficiency & 6.2 & 1.4 & 1.8 & N/A & 0.0 \\
ACTH deficiency & 14.5 & 6.4 & 0.9 & N/A & 3.0 \\
Anterior panhypopituitarism & 11.8 & 3.5 & 10.0 & N/A & 3.0 \\
DI & 18.7 & 6.4 & 5.5 & N/A & 0.0 \\
Obesity & 2.1 & 0.7 & 2.7 & N/A & 1.5 \\
Any endocrinopathy & 51.9 & 19.9 & 20.0 & N/A & 18.2 \\
\hline
\end{tabular}




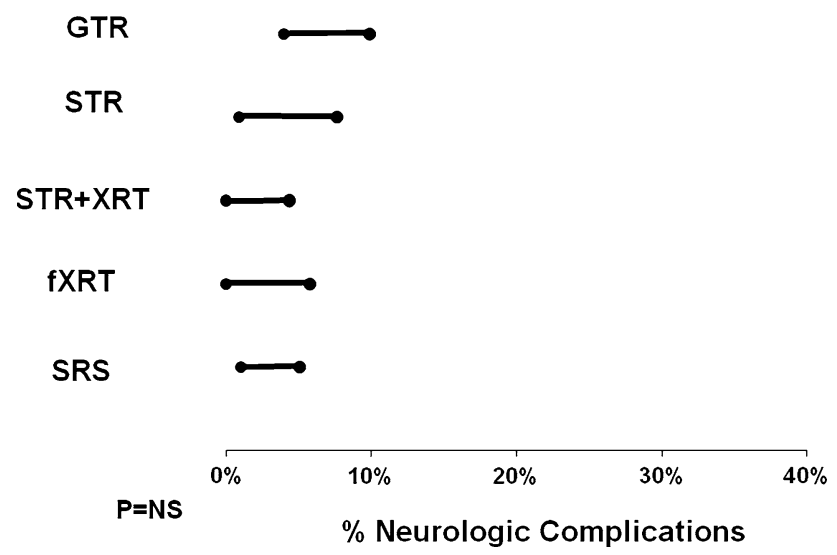

Fig. 2 Comparison of 95\% confidence intervals of rates of neurologic injury for patients treated with different modalities for craniopharyngioma

There was a statistical trend towards worse visual outcomes in patients receiving XRT after STR compared to GTR or STR alone $(\mathrm{GTR}=3.5 \%$ vs. STR $2.1 \%$ vs. STR + XRT $6.4 \%, P=0.11)$. Visual outcomes did not differ between patients receiving fXRT and those receiving SRS (11.1 vs. $6.1 \%, P=$ NS) (Fig. 2).

\section{Univariate risk factors for morbidity after craniopharyngioma surgery}

Table 4 demonstrates univariate comparisons of rates of morbidities with patients stratified by age, tumor size, and extent of hypothalamic involvement. Note that in our univariate analysis, Patient age was not a significant univariate predictor of any form of complication, regardless of where the cut-off was placed in this analysis (one such analysis is provided in Table 4). Extensive hypothalamic involvement did increase the risk of endocrinologic complications, however this was not an independent predictor of morbidity when extent of resection was controlled for (Table 5).

As stated in the methods, while tumor size is a variable of interest, it is inconsistently presented in most studies, and we were only able to collect data on tumor size for 87 patients. Because these data were not enough to include in the multivariate regression modeling, we present only univariate data regarding the relationship between tumor size and complications. Patients undergoing surgery for tumors with a size greater than or equal to $3 \mathrm{~cm}$ experienced a statistical trend towards a higher rate of neurologic complications compared to patients with smaller tumors (10 vs. $0 \%, P=0.06$ ) (Table 4). The rates of endocrinologic, vascular, and visual complications were similar between patients with larger and smaller tumors (Fig. 3).
Table 4 Univariate analyses of the effect of potential confounding variables on rates of neurologic, endocrinologic, vascular, and visual morbidity in the published literature

\begin{tabular}{|c|c|c|c|c|}
\hline & Neurologic & Endocrine & Vascular & Visual \\
\hline \multicolumn{5}{|c|}{ \# Patients in study } \\
\hline $1-10$ & $9 \%$ & $2 \%$ & $1 \%$ & $6 \%$ \\
\hline $11-20$ & $2 \%$ & $7 \%$ & $0 \%$ & $2 \%$ \\
\hline \multirow[t]{2}{*}{$21+$} & $1 \%$ & $1 \%$ & $0 \%$ & $4 \%$ \\
\hline & $P<0.001$ & $P<0.01$ & $P=0.12$ & $P=0.45$ \\
\hline \multicolumn{5}{|l|}{ Patient age } \\
\hline $0-2$ & $9 \%$ & $48 \%$ & $0 \%$ & $4 \%$ \\
\hline $2.1-5$ & $5 \%$ & $41 \%$ & $0 \%$ & $0 \%$ \\
\hline $5.1-10$ & $5 \%$ & $44 \%$ & $1 \%$ & $2 \%$ \\
\hline $11-20$ & $5 \%$ & $34 \%$ & $0 \%$ & $2 \%$ \\
\hline $21-50$ & $5 \%$ & $37 \%$ & $1 \%$ & $4 \%$ \\
\hline \multirow[t]{2}{*}{$51+$} & $2 \%$ & $31 \%$ & $0 \%$ & $3 \%$ \\
\hline & $P=0.84$ & $P=0.41$ & $P=0.85$ & $P=0.73$ \\
\hline \multicolumn{5}{|l|}{ Tumor size } \\
\hline$<3 \mathrm{~cm}$ & $0 \%$ & $36 \%$ & $0 \%$ & $6 \%$ \\
\hline \multirow[t]{2}{*}{$\geq 3 \mathrm{~cm}$} & $10 \%$ & $43 \%$ & $2 \%$ & $0 \%$ \\
\hline & $P=0.06$ & $P=0.33$ & $P=0.59$ & $P=0.16$ \\
\hline \multicolumn{5}{|c|}{ Hypothalamic involvement } \\
\hline Minor or none & $5 \%$ & $40 \%$ & $5 \%$ & $3 \%$ \\
\hline \multirow[t]{2}{*}{ Extensive } & $5 \%$ & $33 \%$ & $5 \%$ & $5 \%$ \\
\hline & $P=0.50$ & $P=0.09$ & $P=0.43$ & $P=0.35$ \\
\hline
\end{tabular}

Table 5 Multivariate logistic regression demonstrating the risk of neurologic and endocrinologic morbidity controlling for extent of resection, study size, and presence of extensive hypothalamic involvement

\begin{tabular}{|c|c|c|c|c|}
\hline & \multirow[t]{2}{*}{ OR } & \multicolumn{2}{|c|}{$95 \% \mathrm{CI}$} & \multirow[t]{2}{*}{$P$-value } \\
\hline & & - & + & \\
\hline \multicolumn{5}{|l|}{ Neurologic } \\
\hline GTR & 5.05 & 1.15 & 22.21 & 0.03 \\
\hline STR & 2.41 & 0.45 & 12.79 & 0.30 \\
\hline Study size $1-10$ & 2.54 & 1.02 & 6.29 & 0.04 \\
\hline Study size $11-20$ & 0.31 & 0.06 & 1.53 & 0.15 \\
\hline \multicolumn{5}{|l|}{ Endocrine } \\
\hline $\begin{array}{l}\text { Extensive hypothalamic } \\
\text { involvement }\end{array}$ & 1.28 & 0.78 & 2.08 & 0.33 \\
\hline GTR & 3.45 & 2.05 & 5.81 & $<0.00001$ \\
\hline STR & 1.89 & 1.05 & 3.38 & 0.03 \\
\hline Study size $1-10$ & 1.02 & 0.66 & 1.58 & 0.92 \\
\hline Study size $11-20$ & 0.61 & 0.35 & 1.05 & 0.08 \\
\hline
\end{tabular}

Note that the odds ratio for the GTR and STR groups are expressed relative to the STR + XRT group, and that the odds ratios for the study size groups are expressed relative to studies with the group with the largest study size 


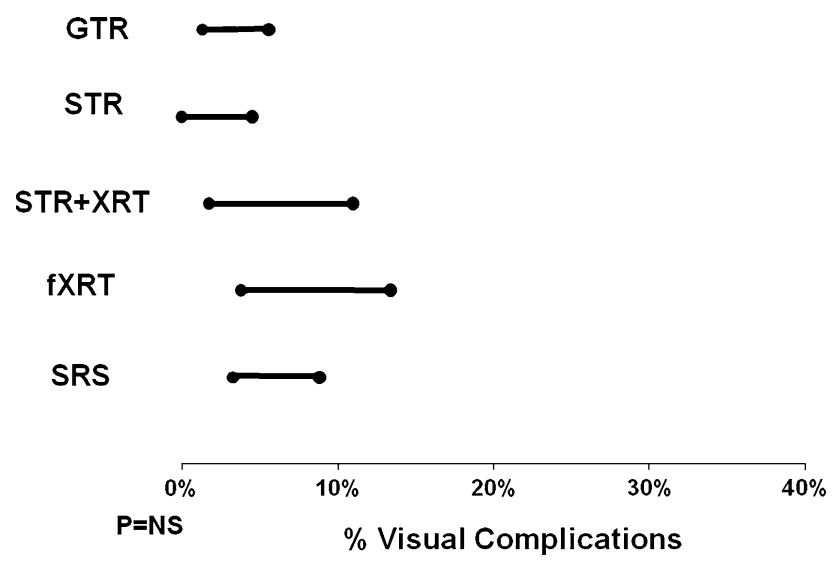

Fig. 3 Comparison of $95 \%$ confidence intervals of rates of visual compromise for patients treated with different modalities for craniopharyngioma

The effect of surgical experience on rates of morbidity following treatment for craniopharyngioma

Surgical experience is generally not specifically reported in craniopharyngioma series in the literature. Using the sample size in these studies as a surrogate for surgical experience, we found a significant reduction in rates of most complications with increasing sample size (Table 4). More specifically, there was a linear decrease in the rates of neurologic complications with increasing study sample size (1-10 patients: $9 \%, 11-20$ patients: $2 \%, 21+$ patients: $1 \%$, $P<0.0001$ ), and a decrease in rates of endocrinopathy favoring studies larger than 20 patients (1-10 patients: $2 \%$, 11-20 patients: $7 \%, 21+$ patients: $1 \%, P<0.01)$. Vascular injuries were also only reported in small series $1-10$ patients: $1 \%, 11-20$ patients: $0 \%, 21+$ patients: $0 \%$, $P=0.12$ ), however this did not reach statistical significance due to the small number of events. Rates of visual complications did not differ between groups of different sample size (1-10 patients: $6 \%, 11-20$ patients: $2 \%, 21+$ patients: $4 \%, P=0.45)$.

On multivariate analysis, studies with small sample sizes remained an independent predictor of increased rates of neurologic morbidity compared to those with large sample size $(\mathrm{OR}=2.54,95 \% \mathrm{CI}=1.02-6.29, P=0.04)$ (Table 5), after controlling for treatment paradigm administered. Study sample size was not an independent predictor of endocrinologic morbidity on multivariate analysis.

\section{Discussion}

Currently, there are few definitive studies regarding management strategies for patients with craniopharyngiomas. This study aims to utilize a systematic collection of the published data on craniopharyngioma, to critically evaluate the idea that subtotal resection with adjuvant radiotherapy can serve as a desirable replacement for gross total resection, with lower post-surgical rates of monohormonal and panhormonal hypothalamic/pituitary endocrinopathy.

Based on our analyses, endocrinopathy is a common iatrogenic complication of treatment of craniopharyngiomas with either surgical resection or radiosurgery, however it is not unexpectedly higher with surgery. Gross total resection markedly increases the rate of hormonal disturbances compared to subtotal resection with or without radiotherapy, with over half of patients experiencing at least one endocrinopathy, and over $10 \%$ of patients being left with panhypopituitarism. Even after correcting for as many covariates as the data would allow, GTR still increased the rate of post-operative endocrinopathy by over three fold. These data support the concept that attempting gross total resection in these lesions is a difficult trade of endocrine function for tumor control, and that subtotal resection might be better for the patient's overall quality of life. Further, previous work focusing on craniopharyngioma suggests that craniopharyngiomas frequently recur despite GTR, and that subtotal resection followed by adjuvant radiotherapy provides similar rates of tumor control to that achieved with gross total resection [282]. Taken together, these data argue that gross total resection of craniopharyngiomas may not be the best treatment option for most patients, however further work specifically focusing on the quality of life concerns of patients undergoing these treatment paradigms is needed to definitively conclude that STR + XRT is better for the patients than GTR.

The remaining argument against adjuvant radiation in this region is the risk of visual deterioration with administering radiotherapy or radiosurgery in close proximity to the optic apparatus. In our study, all irradiated patient cohorts experienced an increased rate of visual compromise compared to surgery only cohorts. While adjuvant radiotherapy following subtotal cytoreductive surgery did not reach statistical significance for worse visual outcomes, It is possible that a lack of statistical power in our cohort prevented statistical significance that would have been demonstrated by a larger study. It is important to note that this difference might be as large as a $10 \%$ in visual decline over GTR at the extremes of the confidence intervals, which would be a serious argument in favor of eliminating the need for XRT with GTR. This idea clearly deserves additional inquiry, especially for driving subtotal resections towards a targeted attack aimed at creating distance between the tumor and the optic apparatus.

Additionally, our analysis demonstrates that experience with craniopharyngiomas matters, and that experienced surgeons have lower rates of complications, even after 
correcting for tumor characteristics, and surgical philosophy. More specifically, using study size as a surrogate for surgical experience, more experienced surgeons have lower rates of neurologic complications than less experienced surgeons. We speculate that increased familiarity with the pathoanatomy of these tumors, combined with decreased need for brain retraction by experienced surgeons, leads to decreased rates of injury of surrounding neural structures.

\section{Study limitations}

While these findings represent a helpful summary of the published literature on this topic, an analysis of published data is limited by the data published by others, and may reflect source study biases. It is impossible for us to control for the quality of the data reported in the literature. For example, the majority of this data set is derived from selfreported outcomes largely assessed by the treating surgeon and colleagues. It is impossible for us to assess or control for the quality of the data reported in the literature, or the unwillingness to report complications. Such omissions would inevitably change the rates reported in our study. Further, subjectively defined variables, such as histologic diagnosis, extent of resection, and the adequacy of radiation therapy likely vary between studies, and we cannot independently confirm the validity of these definitions in other groups' publications.

Finally, due to the diverse range of data presentation, the number of variables able to be studied and controlled for is limited. Variables that might be of interest which are inconsistently presented across studies cannot be reviewed. Specifically, we cannot completely control for the effect of tumor size on rates of complications, because unfortunately, not everyone publishes these data.

\section{Conclusion}

In this study, we summarized and compared the rates of endocrine, neurologic, vascular, and visual complications reported in craniopharyngioma patients. Given the difficulty in obtaining class 1 data regarding the treatment of this tumor, this study can serve as an estimate of expected outcomes for these patients, and guide decision making until these data become available.

Acknowledgments Dr Parsa is supported, in part, by the Reza and Georgianna Khatib endowed chair in skull base tumor surgery. Dr Sughrue is supported by the AANS NREF. Mr Rutkowski is supported by the Doris Duke foundation. Mr Kane is supported by the Howard Hughes Medical Foundation and the Ivy Foundation.
Open Access This article is distributed under the terms of the Creative Commons Attribution Noncommercial License which permits any noncommercial use, distribution, and reproduction in any medium, provided the original author(s) and source are credited.

\section{References}

1. Habrand JL, Saran F, Alapetite C, Noel G, El Boustany R, Grill J (2006) Radiation therapy in the management of craniopharyngioma: current concepts and future developments. J Pediatr Endocrinol Metab 19 Suppl 1:389-394

2. Merchant TE, Kiehna EN, Kun LE, Mulhern RK, Li C, Xiong X, Boop FA, Sanford RA (2006) Phase II trial of conformal radiation therapy for pediatric patients with craniopharyngioma and correlation of surgical factors and radiation dosimetry with change in cognitive function. J Neurosurg 104:94-102

3. Minniti G, Saran F, Traish D, Soomal R, Sardell S, Gonsalves A, Ashley S, Warrington J, Burke K, Mosleh-Shirazi A, Brada M (2007) Fractionated stereotactic conformal radiotherapy following conservative surgery in the control of craniopharyngiomas. Radiother Oncol 82:90-95

4. Scarzello G, Buzzaccarini MS, Perilongo G, Viscardi E, Faggin R, Carollo C, Calderone M, Franchi A, Sotti G (2006) Acute and late morbidity after limited resection and focal radiation therapy in craniopharyngiomas. J Pediatr Endocrinol Metab 19 Suppl $1: 399-405$

5. Raimondi AJ, Rougerie J (1994) A critical review of personal experiences with craniopharyngioma: clinical history, surgical technique and operative results. 1983. Pediatr Neurosurg 21:134-150 (discussion 151-134)

6. Rienstein S, Adams EF, Pilzer D, Goldring AA, Goldman B, Friedman E (2003) Comparative genomic hybridization analysis of craniopharyngiomas. J Neurosurg 98:162-164

7. Long-term outcomes for surgically resected craniopharyngiomas. Neurosurgery 46: 291-302; discussion 302-295, 2000

8. Abe T, Ludecke DK (1999) Transnasal surgery for infradiaphragmatic craniopharyngiomas in pediatric patients. Neurosurgery 44:957-964 (discussion 964-956)

9. Adamson TE, Wiestler OD, Kleihues P, Yasargil MG (1990) Correlation of clinical and pathological features in surgically treated craniopharyngiomas. J Neurosurg 73:12-17

10. Adeloye A, Nottidge VA, Udi J (1988) Craniopharyngioma in Nigerian children. Childs Nerv Syst 4:128-134

11. Agozzino L, Ferraraccio F, Accardo M, Esposito S, Agozzino M, Cuccurullo L (2006) Morphological and ultrastructural findings of prognostic impact in craniopharyngiomas. Ultrastruct Pathol 30:143-150

12. Albright AL, Hadjipanayis CG, Lunsford LD, Kondziolka D, Pollack IF, Adelson PD (2005) Individualized treatment of pediatric craniopharyngiomas. Childs Nerv Syst 21:649-654

13. Al-Mefty O, Ayoubi S, Kadri PA (2007) The petrosal approach for the total removal of giant retrochiasmatic craniopharyngiomas in children. J Neurosurg 106:87-92

14. al-Mefty O, Kersh JE, Routh A, Smith RR (1990) The long-term side effects of radiation therapy for benign brain tumors in adults. J Neurosurg 73:502-512

15. Amendola BE, Gebarski SS, Bermudez AG (1985) Analysis of treatment results in craniopharyngioma. J Clin Oncol 3:252-258

16. Amendola BE, Wolf A, Coy SR, Amendola MA (2003) Role of radiosurgery in craniopharyngiomas: a preliminary report. Med Pediatr Oncol 41:123-127 
17. Ammirati M, Samii M, Sephernia A (1990) Surgery of large retrochiasmatic craniopharyngiomas in children. Childs Nerv Syst 6:13-17

18. Anderson CA, Wilkening GN, Filley CM, Reardon MS, Kleinschmidt-DeMasters BK (1997) Neurobehavioral outcome in pediatric craniopharyngioma. Pediatr Neurosurg 26:255-260

19. Apuzzo ML, Chikovani OK, Gott PS, Teng EL, Zee CS, Giannotta SL, Weiss MH (1982) Transcallosal, interfornicial approaches for lesions affecting the third ventricle: surgical considerations and consequences. Neurosurgery 10:547-554

20. Aydin Y, Can SM, Gulkilik A, Turkmenoglu O, Alatli C, Ziyal I (1999) Rapid enlargement and recurrence of a preexisting intrasellar craniopharyngioma during the course of two pregnancies. Case report. J Neurosurg 91:322-324

21. Barajas MA, Ramirez-Guzman G, Rodriguez-Vazquez C, Toledo-Buenrostro V, Velasquez-Santana H, del Robles RV, Cuevas-Solorzano A, Rodriguez-Hernandez G (2002) Multimodal management of craniopharyngiomas: neuroendoscopy, microsurgery, and radiosurgery. J Neurosurg 97:607-609

22. Barlas O, Bayindir C, Can M (2000) Interstitial irradiation for craniopharyngioma. Acta Neurochir (Wien) 142:389-395

23. Bartlett JR (1971) Craniopharyngiomas-a summary of 85 cases. J Neurol Neurosurg Psychiatry 34:37-41

24. Barua KK, Ehara K, Kohmura E, Tamaki N (2003) Treatment of recurrent craniopharyngiomas. Kobe J Med Sci 49:123-132

25. Baskin DS, Wilson CB (1986) Surgical management of craniopharyngiomas. A review of 74 cases. J Neurosurg 65:22-27

26. Behari S, Banerji D, Mishra A, Sharma S, Chhabra DK, Jain VK (2003) Intrinsic third ventricular craniopharyngiomas: report on six cases and a review of the literature. Surg Neurol 60:245-252 (discussion 252-243)

27. Belen D, Er U, Yigitkanli K, Bolay H (2007) Delayed neurotoxic complication of intracavitary bleomycin therapy for craniopharyngioma in a child who had previously undergone radiosurgery. Case report. J Neurosurg 106:391-393

28. Berlis A, Vesper J, Ostertag C (2006) Stent placement for intracranial cysts by combined stereotactic/endoscopic surgery. Neurosurgery 59:ONS474-479; discussion ONS479-480

29. Bhagwati SN, Deopujari CE, Parulekar GD (1990) Lamina terminalis approach for retrochiasmal craniopharyngiomas. Childs Nerv Syst 6:425-429

30. Bianco Ade M, Madeira LV, Rosemberg S, Shibata MK (2006) Cortical seeding of a craniopharyngioma after craniotomy: case report. Surg Neurol 66:437-440 (discussion 440)

31. Bin-Abbas B, Mawlawi H, Sakati N, Khafaja Y, Chaudhary MA, Al-Ashwal A (2001) Endocrine sequelae of childhood craniopharyngioma. J Pediatr Endocrinol Metab 14:869-874

32. Blackburn TP, Doughty D, Plowman PN (1999) Stereotactic intracavitary therapy of recurrent cystic craniopharyngioma by instillation of 90yttrium. Br J Neurosurg 13:359-365

33. Boch AL, van Effenterre R, Kujas M (1997) Craniopharyngiomas in two consanguineous siblings: case report. Neurosurgery 41:1185-1187

34. Bohn D, Davids MR, Friedman O, Halperin ML (2005) Acute and fatal hyponatraemia after resection of a craniopharyngioma: a preventable tragedy. QJM 98:691-703

35. Bremer AM, Nguyen TQ, Balsys R (1984) Therapeutic benefits of combination chemotherapy with vincristine, BCNU, and procarbazine on recurrent cystic craniopharyngioma. A case report. J Neurooncol 2:47-51

36. Broggi G, Franzini A, Cajola L, Pluchino F (1994) Cell kinetic investigations in craniopharyngioma: preliminary results and considerations. Pediatr Neurosurg 21 Suppl 1:21-23

37. Buhl R, Nabavi A, Fritsch M, Mehdorn HM (2001) Nasopharyngeal extension of a craniopharyngioma in a 4 year old girl. Acta Neurochir (Wien) 143:1283-1285
38. Bulow B, Attewell R, Hagmar L, Malmstrom P, Nordstrom CH, Erfurth EM (1998) Postoperative prognosis in craniopharyngioma with respect to cardiovascular mortality, survival, and tumor recurrence. J Clin Endocrinol Metab 83:3897-3904

39. Burkey BB, Speyer MT, Maciunas RJ, Fitzpatrick JM, Galloway RL Jr, Allen GS (1998) Sublabial, transseptal, transsphenoidal approach to the pituitary region guided by the ACUSTAR I system. Otolaryngol Head Neck Surg 118:191-194

40. Cabezudo JM, Vaquero J, Areitio E, Martinez R, de Sola RG, Bravo G (1981) Craniopharyngiomas: a critical approach to treatment. J Neurosurg 55:371-375

41. Caceres A (2005) Intracavitary therapeutic options in the management of cystic craniopharyngioma. Childs Nerv Syst 21:705718

42. Caldarelli M, di Rocco C, Papacci F, Colosimo C Jr (1998) Management of recurrent craniopharyngioma. Acta Neurochir (Wien) 140:447-454

43. Caldarelli M, Massimi L, Tamburrini G, Cappa M, Di Rocco C (2005) Long-term results of the surgical treatment of craniopharyngioma: the experience at the Policlinico Gemelli, Catholic University, Rome. Childs Nerv Syst 21:747-757

44. Calvo FA, Hornedo J, Arellano A, Sachetti A, de la Torre A, Aragon G, Otero J (1983) Radiation therapy in craniopharyngiomas. Int J Radiat Oncol Biol Phys 9:493-496

45. Cavalheiro S, Dastoli PA, Silva NS, Toledo S, Lederman H, da Silva MC (2005) Use of interferon alpha in intratumoral chemotherapy for cystic craniopharyngioma. Childs Nerv Syst 21:719-724

46. Cavazzuti V, Fischer EG, Welch K, Belli JA, Winston KR (1983) Neurological and psychophysiological sequelae following different treatments of craniopharyngioma in children. J Neurosurg 59:409-417

47. Chakrabarti I, Amar AP, Couldwell W, Weiss MH (2005) Longterm neurological, visual, and endocrine outcomes following transnasal resection of craniopharyngioma. J Neurosurg 102:650-657

48. Gonc EN, Yordam N, Ozon A, Alikasifoglu A, Kandemir N (2004) Endocrinological outcome of different treatment options in children with craniopharyngioma: a retrospective analysis of 66 cases. Pediatr Neurosurg 40:112-119

49. Gsponer J, De Tribolet N, Deruaz JP, Janzer R, Uske A, Mirimanoff RO, Reymond MJ, Rey F, Temler E, Gaillard RC, Gomez F (1999) Diagnosis, treatment, and outcome of pituitary tumors and other abnormal intrasellar masses. Retrospective analysis of 353 patients. Medicine (Baltimore) 78:236-269

50. Guidetti B, Fraioli B (1979) Craniopharyngiomas. Results of surgical treatment. Acta Neurochir Suppl (Wien) 28:349-351

51. Gupta DK, Ojha BK, Sarkar C, Mahapatra AK, Sharma BS, Mehta VS (2006) Recurrence in pediatric craniopharyngiomas: analysis of clinical and histological features. Childs Nerv Syst 22:50-55

52. Gupta K, Kuhn MJ, Shevlin DW, Wacaser LE (1999) Metastatic craniopharyngioma. AJNR Am J Neuroradiol 20:1059-1060

53. Gurkaynak M, Ozyar E, Zorlu F, Akyol FH, Atahan IL (1994) Results of radiotherapy in craniopharyngiomas analysed by the linear quadratic model. Acta Oncol 33:941-943

54. Habrand JL, Ganry O, Couanet D, Rouxel V, Levy-Piedbois C, Pierre-Kahn A, Kalifa C (1999) The role of radiation therapy in the management of craniopharyngioma: a 25 -year experience and review of the literature. Int $\mathbf{J}$ Radiat Oncol Biol Phys 44:255-263

55. Hader WJ, Steinbok P, Hukin J, Fryer C (2000) Intratumoral therapy with bleomycin for cystic craniopharyngiomas in children. Pediatr Neurosurg 33:211-218

56. Hafez MA, ElMekkawy S, AbdelBadie H, Mohy M, Omar M (2006) Pediatric craniopharyngioma — rationale for multimodal 
management: the Egyptian experience. J Pediatr Endocrinol Metab 19 Suppl 1:371-380

57. Hamamoto Y, Niino K, Adachi M, Hosoya T (2002) MR and CT findings of craniopharyngioma during and after radiation therapy. Neuroradiology 44:118-122

58. Hamlat A, Morandi X, Riffaud L, Carsin-Nicol B, Haegelen C, Helal H, Brassier G (2008) Transtemporal-transchoroidal approach and its transamygdala extension to the posterior chiasmatic cistern and diencephalo-mesencephalic lesions. Acta Neurochir (Wien) 150:317-327 (discussion 327-318)

59. Hargrave DR (2006) Does chemotherapy have a role in the management of craniopharyngioma? J Pediatr Endocrinol Metab 19 Suppl 1:407-412

60. Hasegawa T, Kondziolka D, Hadjipanayis CG, Lunsford LD (2004) Management of cystic craniopharyngiomas with phosphorus-32 intracavitary irradiation. Neurosurgery 54:813-820 (discussion 820-812)

61. Hoff JT, Patterson RH Jr (1972) Craniopharyngiomas in children and adults. J Neurosurg 36:299-302

62. Hoffman HJ (1985) Craniopharyngiomas. Can J Neurol Sci $12: 348-352$

63. Hoffman HJ, De Silva M, Humphreys RP, Drake JM, Smith ML, Blaser SI (1992) Aggressive surgical management of craniopharyngiomas in children. J Neurosurg 76:47-52

64. Honegger J, Buchfelder M, Fahlbusch R (1999) Surgical treatment of craniopharyngiomas: endocrinological results. J Neurosurg 90:251-257

65. Hoogenhout J, Otten BJ, Kazem I, Stoelinga GB, Walder AH (1984) Surgery and radiation therapy in the management of craniopharyngiomas. Int J Radiat Oncol Biol Phys 10:22932297

66. Hukin J, Steinbok P, Lafay-Cousin L, Hendson G, Strother D, Mercier C, Samson Y, Howes W, Bouffet E (2007) Intracystic bleomycin therapy for craniopharyngioma in children: the Canadian experience. Cancer 109:2124-2131

67. Hukin J, Visser J, Sargent M, Goddard K, Fryer C, Steinbok P (2005) Childhood craniopharyngioma: Vancouver experience. Childs Nerv Syst 21:758-765

68. Im SH, Wang KC, Kim SK, Chung YN, Kim HS, Lee CH, Cho BK (2003) Transsphenoidal microsurgery for pediatric craniopharyngioma: special considerations regarding indications and method. Pediatr Neurosurg 39:97-103

69. Inoue HK, Fujimaki H, Kohga H, Ono N, Hirato M, Ohye C (1997) Basal interhemispheric supra- and/or infrachiasmal approaches via superomedial orbitotomy for hypothalamic lesions: preservation of hypothalamo-pituitary functions in combination treatment with radiosurgery. Childs Nerv Syst 13:250-256

70. Isaac MA, Hahn SS, Kim JA, Bogart JA, Chung CT (2001) Management of craniopharyngioma. Cancer J 7:516-520

71. Israel ZH, Pomeranz S (1995) Intracranial craniopharyngioma seeding following radical resection. Pediatr Neurosurg 22:210213

72. Ito M, Jamshidi J, Yamanaka K (2001) Does craniopharyngioma metastasize? Case report and review of the literature. Neurosurgery 48:933-935 (discussion 935-936)

73. Ivkov M, Ribaric I, Slavik E, Antunovic V, Samardzic M, Djordjevic M (1979) Surgical treatment of craniopharyngiomas in adults. Acta Neurochir Suppl (Wien) 28:352-356

74. Jackson AS, St George EJ, Hayward RJ, Plowman PN (2003) Stereotactic radiosurgery. XVII: recurrent intrasellar craniopharyngioma. Br J Neurosurg 17:138-143

75. Jakacki RI, Cohen BH, Jamison C, Mathews VP, Arenson E, Longee DC, Hilden J, Cornelius A, Needle M, Heilman D, Boaz JC, Luerssen TG (2000) Phase II evaluation of interferon-alpha2a for progressive or recurrent craniopharyngiomas. J Neurosurg 92:255-260
76. Jeong IH, Lee JK, Moon KS, Joo SP, Kwak HJ, Kim TS, Kim JH, Kim SH (2006) Ectopic recurrence of craniopharyngioma: a case report and review of the literature. J Neurooncol 79:191-195

77. Jialal I, Reddi K, Omar MA, Van Dellen JR, Joubert SM (1986) Pituitary tumours in African and Indian patients. Trop Geogr Med 38:175-179

78. Joki T, Oi S, Babapour B, Kaito N, Ohashi K, Ebara M, Kato M, Abe T (2002) Neuroendoscopic placement of Ommaya reservoir into a cystic craniopharyngioma. Childs Nerv Syst 18:629-633

79. Jooma R, Kendall BE (1982) Intracranial tumours in the first year of life. Neuroradiology 23:267-274

80. Julow J, Backlund EO, Lanyi F, Hajda M, Balint K, Nyary I, Szeifert GT (2007) Long-term results and late complications after intracavitary yttrium-90 colloid irradiation of recurrent cystic craniopharyngiomas. Neurosurgery 61:288-295 (discussion 295-286)

81. Julow J, Lanyi F, Hajda M, Simkovics M, Arany I, Toth S, Pasztor E (1985) The radiotherapy of cystic craniopharyngioma with intracystic installation of $90 \mathrm{Y}$ silicate colloid. Acta Neurochir (Wien) 74:94-99

82. Kabil MS, Shahinian HK (2005) Application of the supraorbital endoscopic approach to tumors of the anterior cranial base. $\mathbf{J}$ Craniofac Surg 16:1070-1074 (discussion 1075)

83. Kalapurakal JA, Goldman S, Hsieh YC, Tomita T, Marymont MH (2000) Clinical outcome in children with recurrent craniopharyngioma after primary surgery. Cancer J 6:388-393

84. Kalapurakal JA, Goldman S, Hsieh YC, Tomita T, Marymont MH (2003) Clinical outcome in children with craniopharyngioma treated with primary surgery and radiotherapy deferred until relapse. Med Pediatr Oncol 40:214-218

85. Kang JK, Song JU (1988) Results of the management of craniopharyngioma in children. An endocrinological approach to the treatment. Childs Nerv Syst 4:135-138

86. Karavitaki N, Brufani C, Warner JT, Adams CB, Richards P, Ansorge O, Shine B, Turner HE, Wass JA (2005) Craniopharyngiomas in children and adults: systematic analysis of 121 cases with long-term follow-up. Clin Endocrinol (Oxf) 62:397-409

87. Katz EL (1975) Late results of radical excision of craniopharyngiomas in children. J Neurosurg 42:86-93

88. Kawaguchi T, Fujimura M, Shirane R, Shoji T, Watanabe M, Tominaga $\mathrm{T}$ (2005) Ectopic recurrence of craniopharyngioma. J Clin Neurosci 12:307-309

89. Keohane C, Hally M, Ryder DQ, Buckley TF (1994) Late recurrence of craniopharyngioma in the cerebellopontine angle in a fertile woman. J Neurol Neurosurg Psychiatry 57:873-874

90. Khafaga Y, Jenkin D, Kanaan I, Hassounah M, Al Shabanah M, Gray A (1998) Craniopharyngioma in children. Int J Radiat Oncol Biol Phys 42:601-606

91. Kim MS, Lee SI, Sim SH (1999) Brain tumors with cysts treated with Gamma Knife radiosurgery: is microsurgery indicated? Stereotact Funct Neurosurg 72 Suppl 1:38-44

92. Kim SD, Park JY, Park J, Lee JB, Kim SH, Lim DJ (2007) Radiological findings following postsurgical intratumoral bleomycin injection for cystic craniopharyngioma. Clin Neurol Neurosurg 109:236-241

93. Kim SK, Wang KC, Shin SH, Choe G, Chi JG, Cho BK (2001) Radical excision of pediatric craniopharyngioma: recurrence pattern and prognostic factors. Childs Nerv Syst 17:531-536 (discussion 537)

94. Chen C, Okera S, Davies PE, Selva D, Crompton JL (2003) Craniopharyngioma: a review of long-term visual outcome. Clin Experiment Ophthalmol 31:220-228

95. Chiou SM, Lunsford LD, Niranjan A, Kondziolka D, Flickinger JC (2001) Stereotactic radiosurgery of residual or recurrent craniopharyngioma, after surgery, with or without radiation therapy. Neuro Oncol 3:159-166 
96. Chung WY, Pan DH, Shiau CY, Guo WY, Wang LW (2000) Gamma knife radiosurgery for craniopharyngiomas. J Neurosurg 93 Suppl 3:47-56

97. Chung WY, Pan HC, Guo WY, Shiau CY, Wang LW, Wu HM, Lee LS (1998) Protection of visual pathway in gamma knife radiosurgery for craniopharyngiomas. Stereotact Funct Neurosurg 70 Suppl 1:139-151

98. Cinalli G, Spennato P, Cianciulli E, Fiorillo A, Di Maio S, Maggi G (2006) The role of transventricular neuroendoscopy in the management of craniopharyngiomas: three patient reports and review of the literature. J Pediatr Endocrinol Metab 19 Suppl 1:341-354

99. Clayton PE, Price DA, Shalet SM, Gattemaneni HR (1988) Craniopharyngioma recurrence and growth hormone therapy. Lancet 1:642

100. Colangelo M, Ambrosio A, Ambrosio C (1990) Neurological and behavioral sequelae following different approaches to craniopharyngioma. Long-term follow-up review and therapeutic guidelines. Childs Nerv Syst 6:379-382

101. Combs SE, Thilmann C, Huber PE, Hoess A, Debus J, SchulzErtner D (2007) Achievement of long-term local control in patients with craniopharyngiomas using high precision stereotactic radiotherapy. Cancer 109:2308-2314

102. Connolly ES Jr, Winfree CJ, Carmel PW (1997) Giant posterior fossa cystic craniopharyngiomas presenting with hearing loss. Report of three cases and review of the literature. Surg Neurol 47:291-299

103. Couldwell WT, Weiss MH, Rabb C, Liu JK, Apfelbaum RI, Fukushima T (2004) Variations on the standard transsphenoidal approach to the sellar region, with emphasis on the extended approaches and parasellar approaches: surgical experience in 105 cases. Neurosurgery 55:539-547 (discussion 547-550)

104. Crotty TB, Scheithauer BW, Young WF Jr, Davis DH, Shaw EG, Miller GM, Burger PC (1995) Papillary craniopharyngioma: a clinicopathological study of 48 cases. J Neurosurg 83:206-214

105. Danoff BF, Cowchock FS, Kramer S (1983) Childhood craniopharyngioma: survival, local control, endocrine and neurologic function following radiotherapy. Int J Radiat Oncol Biol Phys 9:171-175

106. Dashora U, Mathias D, James A, Zammit-Maempel I, Perros P (2002) Management of recurrent pituitary cysts with pituitarynasal drain. Pituitary 5:225-233

107. Davies MJ, King TT, Metcalfe KA, Monson JP (1997) Intraventricular craniopharyngioma: a long-term follow-up of six cases. Br J Neurosurg 11:533-541

108. Day JD, Giannotta SL, Fukushima T (1994) Extradural temporopolar approach to lesions of the upper basilar artery and infrachiasmatic region. J Neurosurg 81:230-235

109. Delitala A, Brunori A, Chiappetta F (2004) Purely neuroendoscopic transventricular management of cystic craniopharyngiomas. Childs Nerv Syst 20:858-862

110. Demaerel P, Moseley IF, Scaravilli F (1993) Recurrent craniopharyngioma invading the orbit, cavernous sinus and skull base: a case report. Neuroradiology 35:261-263

111. DeVile CJ, Grant DB, Hayward RD, Stanhope R (1996) Growth and endocrine sequelae of craniopharyngioma. Arch Dis Child 75:108-114

112. Dhellemmes P, Vinchon M (2006) Radical resection for craniopharyngiomas in children: surgical technique and clinical results. J Pediatr Endocrinol Metab 19 Suppl 1:329-335

113. Di Rocco C, Caldarelli M, Tamburrini G, Massimi L (2006) Surgical management of craniopharyngiomas - experience with a pediatric series. J Pediatr Endocrinol Metab 19 Suppl 1:355-366

114. Djordjevic M, Djordjevic Z, Janicijevic M, Nestorovic B, Stefanovic B, Ivkov M (1979) Surgical treatment of craniopharyngiomas in children. Acta Neurochir Suppl (Wien) 28:344-347

115. Economos D (1979) Systemic shunting of residual intraparenchymatous cystic craniopharyngioma. Acta Neurochir Suppl (Wien) 28:363-366

116. el Gammal T, Brooks BS, Hoffman WH (1989) MR imaging of the ectopic bright signal of posterior pituitary regeneration. AJNR Am J Neuroradiol 10:323-328

117. Eldevik OP, Blaivas M, Gabrielsen TO, Hald JK, Chandler WF (1996) Craniopharyngioma: radiologic and histologic findings and recurrence. AJNR Am J Neuroradiol 17:1427-1439

118. Elwatidy SM, Jamjoom ZA, Jamjoom AB, Yakoub AO (2002) Craniopharyngioma. Analysis of factors that affect the outcome. Saudi Med J 23:34-38

119. Ersahin Y, Yurtseven T, Ozgiray E, Mutluer S (2005) Craniopharyngiomas in children: Turkey experience. Childs Nerv Syst 21:766-772

120. Fahlbusch R, Honegger J, Paulus W, Huk W, Buchfelder M (1999) Surgical treatment of craniopharyngiomas: experience with 168 patients. J Neurosurg 90:237-250

121. Fischer EG, Welch K, Shillito J Jr, Winston KR, Tarbell NJ (1990) Craniopharyngiomas in children. Long-term effects of conservative surgical procedures combined with radiation therapy. J Neurosurg 73:534-540

122. Fisher PG, Jenab J, Gopldthwaite PT, Tihan T, Wharam MD, Foer DR, Burger PC (1998) Outcomes and failure patterns in childhood craniopharyngiomas. Childs Nerv Syst 14: $558-563$

123. Fitzek MM, Linggood RM, Adams J, Munzenrider JE (2006) Combined proton and photon irradiation for craniopharyngioma: long-term results of the early cohort of patients treated at Harvard Cyclotron Laboratory and Massachusetts General Hospital. Int J Radiat Oncol Biol Phys 64:1348-1354

124. Flickinger JC, Deutsch M, Lunsford LD (1989) Repeat megavoltage irradiation of pituitary and suprasellar tumors. Int $\mathrm{J}$ Radiat Oncol Biol Phys 17:171-175

125. Flickinger JC, Lunsford LD, Singer J, Cano ER, Deutsch M (1990) Megavoltage external beam irradiation of craniopharyngiomas: analysis of tumor control and morbidity. Int J Radiat Oncol Biol Phys 19:117-122

126. Fraioli MF, Santoni R, Fraioli C, Contratti F (2006) "Conservative" surgical approach and early postoperative radiotherapy in a patient with a huge cystic craniopharyngioma. Childs Nerv Syst 22:151-155 (discussion 158-163)

127. Frank G, Pasquini E, Doglietto F, Mazzatenta D, Sciarretta V, Farneti G, Calbucci F (2006) The endoscopic extended transsphenoidal approach for craniopharyngiomas. Neurosurgery 59:ONS75-83 (discussion ONS75-83)

128. Freeman CR, Souhami L, Caron JL, Villemure JG, Olivier A, Montes J, Farmer JP, Podgorsak EB (1994) Stereotactic external beam irradiation in previously untreated brain tumors in children and adolescents. Med Pediatr Oncol 22:173-180

129. Frisen L, Sjostrand J, Norrsell K, Lindgren S (1976) Cyclic compression of the intracranial optic nerve: patterns of visual failure and recovery. J Neurol Neurosurg Psychiatry 39:1109_ 1113

130. Garcia-Uria J (1978) Surgical experience with craniopharyngioma in adults. Surg Neurol 9:11-14

131. Ghatak NR, White BE (1969) Delayed radiation necrosis of the hypothalamus. Report of a case simulating recurrent craniopharyngioma. Arch Neurol 21:425-430

132. Gil Z, Constantini S, Spektor S, Abergel A, Khafif A, BeniAdani L, Leonor TL, DeRowe A, Fliss DM (2005) Skull base approaches in the pediatric population. Head Neck 27:682-689

133. Giller CA, Berger BD, Pistenmaa DA, Sklar F, Weprin B, Shapiro K, Winick N, Mulne AF, Delp JL, Gilio JP, Gall KP, 
Dicke KA, Swift D, Sacco D, Harris-Henderson K, Bowers D (2005) Robotically guided radiosurgery for children. Pediatr Blood Cancer 45:304-310

134. Gomez-Daspet J, Elko L, Grebenev D, Vesely DL (2002) Survival with serum sodium level of $180 \mathrm{mEq} / \mathrm{L}$ : permanent disorientation to place and time. Am J Med Sci 324:321-325

135. Kobayashi T, Kida Y, Mori Y, Hasegawa T (2005) Long-term results of gamma knife surgery for the treatment of craniopharyngioma in 98 consecutive cases. J Neurosurg 103:482-488

136. Kobayashi T, Tanaka T, Kida Y (1994) Stereotactic gamma radiosurgery of craniopharyngiomas. Pediatr Neurosurg 21 Suppl 1:69-74

137. Kodama T, Matsukado Y, Uemura S (1981) Intracapsular irradiation therapy of craniopharyngiomas with radioactive gold: indication and follow-up results. Neurol Med Chir (Tokyo) 21:49-58

138. Kondziolka D, Nathoo N, Flickinger JC, Niranjan A, Maitz AH, Lunsford LD (2003) Long-term results after radiosurgery for benign intracranial tumors. Neurosurgery 53:815-821 (discussion 821-812)

139. Konig A, Ludecke DK, Herrmann HD (1986) Transnasal surgery in the treatment of craniopharyngiomas. Acta Neurochir (Wien) 83:1-7

140. Konovalov AN, Gorelyshev SK (1992) Surgical treatment of anterior third ventricle tumours. Acta Neurochir (Wien) 118:33-39

141. Kramer S, Southard M, Mansfield CM (1968) Radiotherapy in the management of craniopharyngiomas: further experiences and late results. Am J Roentgenol Radium Ther Nucl Med 103:44-52

142. Kranzinger M, Jones N, Rittinger O, Pilz P, Piotrowski WP, Manzl M, Galvan G, Kogelnik HD (2001) Malignant glioma as a secondary malignant neoplasm after radiation therapy for craniopharyngioma: report of a case and review of reported cases. Onkologie 24:66-72

143. Kristopaitis T, Thomas C, Petruzzelli GJ, Lee JM (2000) Malignant craniopharyngioma. Arch Pathol Lab Med 124:1356-1360

144. Kulkarni V, Daniel RT, Pranatartiharan R (2000) Spontaneous intraventricular rupture of craniopharyngioma cyst. Surg Neurol 54:249-253 (discussion 253)

145. Kuwabara S, Seo H, Ishikawa S (1987) Huge, dense, cystic craniopharyngioma with unusual extensions-case report. Neurol Med Chir (Tokyo) 27:37-41

146. Lange M, Kirsch CM, Steude U, Oeckler R (1995) Intracavitary treatment of intrasellar cystic craniopharyngeomas with 90Yttrium by trans-sphenoidal approach - a technical note. Acta Neurochir (Wien) 135:206-209

147. Lapras C, Patet JD, Mottolese C, Gharbi S, Lapras C Jr (1987) Craniopharyngiomas in childhood: analysis of 42 cases. Prog Exp Tumor Res 30:350-358

148. Larijani B, Bastanhagh MH, Pajouhi M, Kargar Shadab F, Vasigh A, Aghakhani S (2004) Presentation and outcome of 93 cases of craniopharyngioma. Eur J Cancer Care (Engl) 13:11-15

149. Laws ER Jr (1994) Transsphenoidal removal of craniopharyngioma. Pediatr Neurosurg 21 Suppl 1:57-63

150. Laws ER Jr, Morris AM, Maartens N (2003) Gliadel for pituitary adenomas and craniopharyngiomas. Neurosurgery 53:255269 (discussion 259-260)

151. Lena G, Paz Paredes A, Scavarda D, Giusiano B (2005) Craniopharyngioma in children: Marseille experience. Childs Nerv Syst 21:778-784

152. Lessell S (1975) Unilateral exophthalmos. Occurrence after treatment for perichiasmatic neoplasms. JAMA 234:305-306

153. Lichter AS, Wara WM, Sheline GE, Townsend JJ, Wilson CB (1977) The treatment of craniopharyngiomas. Int J Radiat Oncol Biol Phys 2:675-683
154. Lin KL, Wang HS, Lui TN (2002) Diagnosis and follow-up of craniopharyngiomas with transcranial Doppler sonography. J Ultrasound Med 21:801-806

155. Lippens RJ, Rotteveel JJ, Otten BJ, Merx H (1998) Chemotherapy with Adriamycin (doxorubicin) and CCNU (lomustine) in four children with recurrent craniopharyngioma. Eur J Paediatr Neurol 2:263-268

156. Liu JM, Garonzik IM, Eberhart CG, Sampath P, Brem H (2002) Ectopic recurrence of craniopharyngioma after an interhemispheric transcallosal approach: case report. Neurosurgery 50:639-644 (discussion 644-635)

157. Locatelli D, Levi D, Rampa F, Pezzotta S, Castelnuovo P (2004) Endoscopic approach for the treatment of relapses in cystic craniopharyngiomas. Childs Nerv Syst 20:863-867

158. Long DM, Chou SN (1973) Transcallosal removal of craniopharyngiomas within the third ventricle. J Neurosurg 39: 563-567

159. Lonjon M, Dran G, Casagrande F, Vandenbos F, Mas JC, Richelme C (2005) Prenatal diagnosis of a craniopharyngioma: a new case with radical surgery and review. Childs Nerv Syst $21: 177-180$

160. Lunsford LD, Pollock BE, Kondziolka DS, Levine G, Flickinger JC (1994) Stereotactic options in the management of craniopharyngioma. Pediatr Neurosurg 21 Suppl 1:90-97

161. Luu QT, Loredo LN, Archambeau JO, Yonemoto LT, Slater JM, Slater JD (2006) Fractionated proton radiation treatment for pediatric craniopharyngioma: preliminary report. Cancer $\mathrm{J}$ $12: 155-159$

162. Lyen KR, Grant DB (1982) Endocrine function, morbidity, and mortality after surgery for craniopharyngioma. Arch Dis Child 57:837-841

163. Madhavan M, JG P, Abdullah Jafri J, Idris Z (2005) Intraventricular squamous papillary craniopharyngioma: report of a case with intraoperative imprint cytology. Acta Cytol 49:431-434

164. Maira G, Anile C, Albanese A, Cabezas D, Pardi F, Vignati A (2004) The role of transsphenoidal surgery in the treatment of craniopharyngiomas. J Neurosurg 100:445-451

165. Maira G, Anile C, Colosimo C, Cabezas D (2000) Craniopharyngiomas of the third ventricle: trans-lamina terminalis approach. Neurosurgery 47:857-863 (discussion 863-855)

166. Maira G, Anile C, Rossi GF, Colosimo C (1995) Surgical treatment of craniopharyngiomas: an evaluation of the transsphenoidal and pterional approaches. Neurosurgery 36:715-724

167. Maira G, Di Rocco C, Anile C, Roselli R (1982) Hyperprolactinemia as the first symptom of craniopharyngioma. Childs Brain 9:205-210

168. Malik JM, Cosgrove GR, VandenBerg SR (1992) Remote recurrence of craniopharyngioma in the epidural space. Case report. J Neurosurg 77:804-807

169. Maniatis AK, Simmons JH, Zeitler PS (2005) Hypothalamic obesity in a patient with craniopharyngioma: dysregulation of neurohormonal control of energy balance. Curr Opin Pediatr $17: 275-279$

170. Maniker AH, Krieger AJ (1996) Rapid recurrence of craniopharyngioma during pregnancy with recovery of vision: a case report. Surg Neurol 45:324-327

171. Mark RJ, Lutge WR, Shimizu KT, Tran LM, Selch MT, Parker RG (1995) Craniopharyngioma: treatment in the CT and MR imaging era. Radiology 197:195-198

172. Mason PW, Krawiecki N, Meacham LR (2002) The use of dextroamphetamine to treat obesity and hyperphagia in children treated for craniopharyngioma. Arch Pediatr Adolesc Med $156: 887-892$

173. Matarazzo P, Genitori L, Lala R, Andreo M, Grossetti R, de Sanctis C (2004) Endocrine function and water metabolism in 
children and adolescents with surgically treated intra/parasellar tumors. J Pediatr Endocrinol Metab 17:1487-1495

174. Matson DD, Crigler JF Jr (1969) Management of craniopharyngioma in childhood. J Neurosurg 30:377-390

175. Matthew DJ, Levin M (1986) Pulmonary thromboembolism in children. Intensive Care Med 12:404-406

176. McMurry FG, Hardy RW Jr, Dohn DF, Sadar E, Gardner WJ (1977) Long term results in the management of craniopharyngiomas. Neurosurgery 1:238-241

177. Merchant TE, Kiehna EN, Sanford RA, Mulhern RK, Thompson SJ, Wilson MW, Lustig RH, Kun LE (2002) Craniopharyngioma: the St. Jude Children's Research Hospital experience 1984-2001. Int J Radiat Oncol Biol Phys 53:533-542

178. Minamida Y, Mikami T, Hashi K, Houkin K (2005) Surgical management of the recurrence and regrowth of craniopharyngiomas. J Neurosurg 103:224-232

179. Moon SH, Kim IH, Park SW, Kim I, Hong S, Park CI, Wang KC, Cho BK (2005) Early adjuvant radiotherapy toward long-term survival and better quality of life for craniopharyngiomas-a study in single institute. Childs Nerv Syst 21: 799-807

180. Mori K, Handa H, Murata T, Takeuchi J, Miwa S, Osaka K (1980) Results of treatment for craniopharyngioma. Childs Brain 6:303-312

181. Mottolese C, Stan H, Hermier M, Berlier P, Convert J, Frappaz D, Lapras C (2001) Intracystic chemotherapy with bleomycin in the treatment of craniopharyngiomas. Childs Nerv Syst 17:724730

182. Mottolese C, Szathmari A, Berlier P, Hermier M (2005) Craniopharyngiomas: our experience in Lyon. Childs Nerv Syst 21:790-798

183. Mudgil AV, Repka MX (2000) Childhood optic atrophy. Clin Experiment Ophthalmol 28:34-37

184. Muller-Scholden J, Lehrnbecher T, Muller HL, Bensch J, Hengen RH, Sorensen N, Stockhausen HB (2000) Radical surgery in a neonate with craniopharyngioma. Report of a case. Pediatr Neurosurg 33:265-269

185. Murphy M, Worth RD, Norris JS (2004) 'Disappearing' recurrent craniopharyngioma. Br J Neurosurg 18:65

186. Nimsky C, Ganslandt O, Hofmann B, Fahlbusch R (2003) Limited benefit of intraoperative low-field magnetic resonance imaging in craniopharyngioma surgery. Neurosurgery 53:72-80 (discussion 80-71)

187. Nishioka H, Ito H, Haraoka J, Hashimoto T, Kato Y (2000) Repeated hemorrhage in ciliated craniopharyngioma-case report. Neurol Med Chir (Tokyo) 40:324-328

188. Niu DM, Guo WY, Pan HC, Wong TT (2002) Rapid enlargement of a residual craniopharyngioma during short-term growth hormone replacement. Childs Nerv Syst 18:164-165

189. Nomura H, Kurimoto M, Nagai S, Hayashi N, Hirashima Y, Tsukamoto E, Endo S (2002) Multiple intracranial seeding of craniopharyngioma after repeated surgery—case report. Neurol Med Chir (Tokyo) 42:268-271

190. Norris JS, Pavaresh M, Afshar F (1998) Primary transsphenoidal microsurgery in the treatment of craniopharyngiomas. $\mathrm{Br} \mathrm{J}$ Neurosurg 12:305-312

191. Novegno F, Di Rocco F, Colosimo C Jr, Lauriola L, Caldarelli M (2002) Ectopic recurrences of craniopharyngioma. Childs Nerv Syst 18:468-473

192. Nyffeler T, Regard M (2001) Kleptomania in a patient with a right frontolimbic lesion. Neuropsychiatry Neuropsychol Behav Neurol 14:73-76

193. Ohmori K, Collins J, Fukushima T (2007) Craniopharyngiomas in children. Pediatr Neurosurg 43:265-278

194. Onoyama Y, Ono K, Yabumoto E, Takeuchi J (1977) Radiation therapy of craniopharyngioma. Radiology 125:799-803
195. Palaoglu S, Akbay A, Mocan G, Onol B, Ozcan OE, Ozgen T, Bertan V (1994) Ossified adamantinous type craniopharyngiomas. A series of 13 patients. Acta Neurochir (Wien) 127:166-169

196. Pan DH, Lee LS, Huang CI, Wong TT (1990) Stereotactic internal irradiation for cystic craniopharyngiomas: a 6-year experience. Stereotact Funct Neurosurg 54-55:525-530

197. Park DH, Park JY, Kim JH, Chung YG, Lee HK, Lee KC, Suh JK (2002) Outcome of postoperative intratumoral bleomycin injection for cystic craniopharyngioma. J Korean Med Sci 17:254-259

198. Pemberton LS, Dougal M, Magee B, Gattamaneni HR (2005) Experience of external beam radiotherapy given adjuvantly or at relapse following surgery for craniopharyngioma. Radiother Oncol 77:99-104

199. Pereira AM, Schmid EM, Schutte PJ, Voormolen JH, Biermasz NR, van Thiel SW, Corssmit EP, Smit JW, Roelfsema F, Romijn JA (2005) High prevalence of long-term cardiovascular, neurological and psychosocial morbidity after treatment for craniopharyngioma. Clin Endocrinol (Oxf) 62:197-204

200. Plowman PN, Wraith C, Royle N, Grossman AB (1999) Stereotactic radiosurgery. IX. Craniopharyngioma: durable complete imaging responses and indications for treatment. $\mathrm{Br} \mathrm{J}$ Neurosurg 13:352-358

201. Pollock BE, Lunsford LD, Kondziolka D, Levine G, Flickinger JC (1995) Phosphorus-32 intracavitary irradiation of cystic craniopharyngiomas: current technique and long-term results. Int J Radiat Oncol Biol Phys 33:437-446

202. Pollock BE, Natt N, Schomberg PJ (2002) Stereotactic management of craniopharyngiomas. Stereotact Funct Neurosurg 79:25-32

203. Pomeranz HD, Aldrich EF (2004) Intrachiasmal craniopharyngioma: treatment with a cisternal catheter drainage and radiation. J Neuroophthalmol 24:27-30

204. Pritz MB (2002) Ruptured true posterior communicating artery aneurysm and cystic craniopharyngioma. Acta Neurochir (Wien) 144:937-939 (discussion 939)

205. Puget S, Garnett M, Wray A, Grill J, Habrand JL, Bodaert N, Zerah M, Bezerra M, Renier D, Pierre-Kahn A, Sainte-Rose C (2007) Pediatric craniopharyngiomas: classification and treatment according to the degree of hypothalamic involvement. J Neurosurg 106:3-12

206. Ragel BT, Bishop FS, Couldwell WT (2007) Recurrent infrasellar clival craniopharyngioma. Acta Neurochir (Wien) 149:729-730 (discussion 730)

207. Ragoowansi AT, Piepgras DG (1991) Postoperative ectopic craniopharyngioma. Case report. J Neurosurg 74:653-655

208. Rajan B, Ashley S, Gorman C, Jose CC, Horwich A, Bloom HJ, Marsh H, Brada M (1993) Craniopharyngioma-a long-term results following limited surgery and radiotherapy. Radiother Oncol 26:1-10

209. Rajan B, Ashley S, Thomas DG, Marsh H, Britton J, Brada M (1997) Craniopharyngioma: improving outcome by early recognition and treatment of acute complications. Int $\mathrm{J}$ Radiat Oncol Biol Phys 37:517-521

210. Ramnarayan R, Sreehari NR, Ninan GK, John KM (2007) Delayed postoperative extradural hematoma. Pediatr Neurosurg 43:113-114

211. Regine WF, Mohiuddin M, Kramer S (1993) Long-term results of pediatric and adult craniopharyngiomas treated with combined surgery and radiation. Radiother Oncol 27:13-21

212. Rehman HU, Atkin SL (1999) Sleep disturbances and cardiac arrhythmia after treatment of a craniopharyngioma. J R Soc Med 92:585-586

213. Richmond IL, Wara WM, Wilson CB (1980) Role of radiation therapy in the management of craniopharyngiomas in children. Neurosurgery 6:513-517 
214. Richmond IL, Wilson CB (1980) Parasellar tumors in children. II. Surgical management, radiation therapy, and follow-up. Childs Brain 7:85-94

215. Rilliet B, Vernet O, Pica A (2005) The Geneva and Lausanne (French-speaking Switzerland) experience: in favor of the transsphenoidal approach when feasible. Childs Nerv Syst 21:725-728

216. Rodriguez FJ, Scheithauer BW, Tsunoda S, Kovacs K, Vidal S, Piepgras DG (2007) The spectrum of malignancy in craniopharyngioma. Am J Surg Pathol 31:1020-1028

217. Rudnick EF, DiNardo LJ (2006) Image-guided endoscopic endonasal resection of a recurrent craniopharyngioma. Am J Otolaryngol 27:266-267

218. Saaf M, Thoren M, Bergstrand CG, Noren G, Rahn T, Tallstedt L, Backlund EO (1989) Treatment of craniopharyngiomas-the stereotactic approach in a ten to twenty-three years' perspective. II. Psychosocial situation and pituitary function. Acta Neurochir (Wien) 99:97-103

219. Samuels MH, Henry P, Kleinschmidt-Demasters B, Lillehei K, Ridgway EC (1991) Pulsatile prolactin secretion in hyperprolactinemia due to presumed pituitary stalk interruption. J Clin Endocrinol Metab 73:1289-1293

220. Schefter JK, Allen G, Cmelak AJ, Johnson M, Toms S, Duggan D, Blevins LS (2002) The utility of external beam radiation and intracystic 32P radiation in the treatment of craniopharyngiomas. J Neurooncol 56:69-78

221. Schulz-Ertner D, Frank C, Herfarth KK, Rhein B, Wannenmacher M, Debus J (2002) Fractionated stereotactic radiotherapy for craniopharyngiomas. Int J Radiat Oncol Biol Phys 54:11141120

222. Scott RM, Hetelekidis S, Barnes PD, Goumnerova L, Tarbell NJ (1994) Surgery, radiation, and combination therapy in the treatment of childhood craniopharyngioma-a 20-year experience. Pediatr Neurosurg 21 Suppl 1:75-81

223. Sener RN, Kismali E, Akyar S, Selcuki M, Yalman O (1997) Large craniopharyngioma extending to the posterior cranial fossa. Magn Reson Imaging 15:1111-1112

224. Sepehrnia A, Samii M, Tatagiba M (1991) Management of intracavernous tumours: an 11-year experience. Acta Neurochir Suppl (Wien) 53:122-126

225. Shapiro K, Till K, Grant DN (1979) Craniopharyngiomas in childhood. A rational approach to treatment. J Neurosurg 50:617-623

226. Shi XE, Wu B, Zhou ZQ, Fan T, Zhang YL (2006) Microsurgical treatment of craniopharyngiomas: report of 284 patients. Chin Med J (Engl) 119:1653-1663

227. Shinohara O, Shinagawa T, Kubota C, Oi S (1997) Spontaneous reduction of a recurrent craniopharyngioma in an 8-year-old female patient: case report. Neurosurgery 41:1188-1190

228. Shirane R, Ching-Chan S, Kusaka Y, Jokura H, Yoshimoto T (2002) Surgical outcomes in 31 patients with craniopharyngiomas extending outside the suprasellar cistern: an evaluation of the frontobasal interhemispheric approach. J Neurosurg 96:704-712

229. Shirane R, Hayashi T, Tominaga T (2005) Fronto-basal interhemispheric approach for craniopharyngiomas extending outside the suprasellar cistern. Childs Nerv Syst 21:669-678

230. Shuman AG, Heth JA, Marentette LJ, Blaivas M, Muraszko KM (2007) Extracranial nasopharyngeal craniopharyngioma: case report. Neurosurgery 60:E780-E781 (discussion E781)

231. Siomin V, Spektor S, Beni-Adani L, Constantini S (2001) Application of the orbito-cranial approach in pediatric neurosurgery. Childs Nerv Syst 17:612-617

232. Smith AR, Elsheikh TM, Silverman JF (1999) Intraoperative cytologic diagnosis of suprasellar and sellar cystic lesions. Diagn Cytopathol 20:137-147
233. Smith D, Finucane F, Phillips J, Baylis PH, Finucane J, Tormey W, Thompson CJ (2004) Abnormal regulation of thirst and vasopressin secretion following surgery for craniopharyngioma. Clin Endocrinol (Oxf) 61:273-279

234. Snow A, Gozal E, Malhotra A, Tiosano D, Perlman R, Vega C, Shahar E, Gozal D, Hochberg Z, Pillar G (2002) Severe hypersomnolence after pituitary/hypothalamic surgery in adolescents: clinical characteristics and potential mechanisms. Pediatrics 110:e74

235. Sorva R, Heiskanen O (1986) Craniopharyngioma in Finland. A study of 123 cases. Acta Neurochir (Wien) 81:85-89

236. Sorva R, Heiskanen O, Perheentupa J (1987) Craniopharyngioma in adults. Ann Clin Res 19:339-343

237. Sorva R, Jaaskinen J, Heiskanen O, Perheentupa J (1988) Postoperative computed tomographic control of 38 patients with craniopharyngioma. Surg Neurol 29:115-119

238. Sosa IJ, Krieger MD, McComb JG (2005) Craniopharyngiomas of childhood: the CHLA experience. Childs Nerv Syst 21:785789

239. Srinivasan J, Dailey AT, Berger MS (1999) The bifrontal olfactory nerve-sparing approach to lesions of the suprasellar region in children. Pediatr Neurosurg 30:245-252

240. Stahnke N, Grubel G, Lagenstein I, Willig RP (1984) Long-term follow-up of children with craniopharyngioma. Eur J Pediatr 142:179-185

241. Stripp DC, Maity A, Janss AJ, Belasco JB, Tochner ZA, Goldwein JW, Moshang T, Rorke LB, Phillips PC, Sutton LN, Shu HK (2004) Surgery with or without radiation therapy in the management of craniopharyngiomas in children and young adults. Int J Radiat Oncol Biol Phys 58:714-720

242. Sung DI (1982) Suprasellar tumors in children: a review of clinical manifestations and managements. Cancer 50:1420-1425

243. Sutton LN, Gusnard D, Bruce DA, Fried A, Packer RJ, Zimmerman RA (1991) Fusiform dilatations of the carotid artery following radical surgery of childhood craniopharyngiomas. J Neurosurg 74:695-700

244. Svien HJ (1965) Surgical experiences with craniopharyngiomas. J Neurosurg 23:148-155

245. Sweet WH (1976) Radical surgical treatment of craniopharyngioma. Clin Neurosurg 23:52-79

246. Symon L (1983) Microsurgery of the hypothalamus with special reference to craniopharyngioma. Neurosurg Rev 6:43-49

247. Symon L (1994) An approach to radical excision of craniopharyngioma by the temporal route. Pediatr Neurosurg 21 Suppl $1: 64-68$

248. Symon L, Pell MF, Habib AH (1991) Radical excision of craniopharyngioma by the temporal route: a review of 50 patients. Br J Neurosurg 5:539-549

249. Symon L, Sprich W (1985) Radical excision of craniopharyngioma. Results in 20 patients. J Neurosurg 62:174-181

250. Taguchi Y, Tanaka K, Miyakita Y, Sekino H, Fujimoto M (2000) Recurrent craniopharyngioma with nasopharyngeal extension. Pediatr Neurosurg 32:140-144

251. Takahashi H, Yamaguchi F, Teramoto A (2005) Long-term outcome and reconsideration of intracystic chemotherapy with bleomycin for craniopharyngioma in children. Childs Nerv Syst 21:701-704

252. Tavangar SM, Larijani B, Mahta A, Hosseini SM, Mehrazine M, Bandarian F (2004) Craniopharyngioma: a clinicopathological study of 141 cases. Endocr Pathol 15:339-344

253. Tena-Suck ML, Salinas-Lara C, Arce-Arellano RI, RembaoBojorquez D, Morales-Espinosa D, Sotelo J, Arrieta O (2006) Clinico-pathological and immunohistochemical characteristics associated to recurrence/regrowth of craniopharyngiomas. Clin Neurol Neurosurg 108:661-669 
254. Thomas RF, Monacci WT, Mair EA (2002) Endoscopic imageguided transethmoid pituitary surgery. Otolaryngol Head Neck Surg 127:409-416

255. Thompson D, Phipps K, Hayward R (2005) Craniopharyngioma in childhood: our evidence-based approach to management. Childs Nerv Syst 21:660-668

256. Thompson IL, Griffin TW, Parker RG, Blasko JC (1978) Craniopharyngioma: the role of radiation therapy. Int $\mathrm{J}$ Radiat Oncol Biol Phys 4:1059-1063

257. Thomsett MJ, Conte FA, Kaplan SL, Grumbach MM (1980) Endocrine and neurologic outcome in childhood craniopharyngioma: Review of effect of treatment in 42 patients. J Pediatr 97:728-735

258. Tomita T, Bowman RM (2005) Craniopharyngiomas in children: surgical experience at Children's Memorial Hospital. Childs Nerv Syst 21:729-746

259. Tomita T, McLone DG (1993) Radical resections of childhood craniopharyngiomas. Pediatr Neurosurg 19:6-14

260. Trejos H, Caceres A, Segura JL (2005) Monstrous craniopharyngioma. Case presentations and term proposal. Childs Nerv Syst 21:1049-1053 (discussion 1054-1045)

261. Ulfarsson E, Lindquist C, Roberts M, Rahn T, Lindquist M, Thoren M, Lippitz B (2002) Gamma knife radiosurgery for craniopharyngiomas: long-term results in the first Swedish patients. J Neurosurg 97:613-622

262. Usanov EI, Hatomkin DM, Nikulina TA, Gorban NA (1999) Craniopharyngioma of the pineal region. Childs Nerv Syst 15:4-7

263. Van den Berge JH, Blaauw G, Breeman WA, Rahmy A, Wijngaarde R (1992) Intracavitary brachytherapy of cystic craniopharyngiomas. J Neurosurg 77:545-550

264. Van Effenterre R, Boch AL (2002) Craniopharyngioma in adults and children: a study of 122 surgical cases. J Neurosurg 97:3-11

265. Varlotto JM, Flickinger JC, Kondziolka D, Lunsford LD, Deutsch M (2002) External beam irradiation of craniopharyngiomas: long-term analysis of tumor control and morbidity. Int J Radiat Oncol Biol Phys 54:492-499

266. Villani RM, Tomei G, Bello L, Sganzerla E, Ambrosi B, Re T, Giovanelli Barilari M (1997) Long-term results of treatment for craniopharyngioma in children. Childs Nerv Syst 13:397-405

267. Voges J, Sturm V, Lehrke R, Treuer H, Gauss C, Berthold F (1997) Cystic craniopharyngioma: long-term results after intracavitary irradiation with stereotactically applied colloidal beta-emitting radioactive sources. Neurosurgery 40:263-269 (discussion 269-270)

268. Vrionis FD, Saatman D, Sorenson J, Brem S (2002) Microscopic paraseptal sphenoidotomy approach for pituitary tumors. Cancer Control 9:223-231
269. Vyramuthu N, Benton TF (1983) The management of craniopharyngioma. Clin Radiol 34:629-632

270. Wara WM, Sneed PK, Larson DA (1994) The role of radiation therapy in the treatment of craniopharyngioma. Pediatr Neurosurg 21 Suppl 1:98-100

271. Weiner HL, Wisoff JH, Rosenberg ME, Kupersmith MJ, Cohen H, Zagzag D, Shiminski-Maher T, Flamm ES, Epstein FJ, Miller DC (1994) Craniopharyngiomas: a clinicopathological analysis of factors predictive of recurrence and functional outcome. Neurosurgery 35:1001-1010 (discussion 1010-1001)

272. Weiss M, Sutton L, Marcial V, Fowble B, Packer R, Zimmerman R, Schut L, Bruce D, D'Angio G (1989) The role of radiation therapy in the management of childhood craniopharyngioma. Int J Radiat Oncol Biol Phys 17:1313-1321

273. Wen BC, Hussey DH, Staples J, Hitchon PW, Jani SK, Vigliotti AP, Doornbos JF (1989) A comparison of the roles of surgery and radiation therapy in the management of craniopharyngiomas. Int J Radiat Oncol Biol Phys 16:17-24

274. Xu JG, You C, Cai BW, Jiang S, Sun H, Guo FY, Yang YB, Wu B (2005) Microsurgical resection of craniopharyngioma of the third ventricle via an improved transventricular approach. Chin Med J (Engl) 118:806-811

275. Yamada Y, Haraoka J, Akimoto J (2006) Ectopic recurrence of craniopharyngioma. Neurol Med Chir (Tokyo) 46:598-600

276. Yu X, Liu Z, Li S (2000) Combined treatment with stereotactic intracavitary irradiation and gamma knife surgery for craniopharyngiomas. Stereotact Funct Neurosurg 75:117-122

277. Zona G, Spaziante R (2006) Management of cystic craniopharyngiomas in childhood by a transsphenoidal approach. J Pediatr Endocrinol Metab 19 Suppl 1:381-388

278. Zuccaro G (2005) Radical resection of craniopharyngioma. Childs Nerv Syst 21:679-690

279. Zuccaro G, Jaimovich R, Mantese B, Monges J (1996) Complications in paediatric craniopharyngioma treatment. Childs Nerv Syst 12:385-390 (discussion 390-381)

280. Hosmer DW, Lemeshow S (2000) Applied logistic regression. Wiley, New York

281. Hosmer DW, Hjort NL (2002) Goodness-of-fit processes for logistic regression: simulation results. Stat Med 21:2723-2738

282. Yang I, Sughrue ME, Rutkowski MJ, Kaur R, Ivan ME, Aranda D, Barani IJ, Parsa AT (2010) Craniopharyngioma: a comparison of tumor control with various treatment strategies. Neurosurg Focus 28: E5 